\section{Direct Primer Walking on P1 Plasmid DNA}

BioTechniques 23:98-100 (July 1997)

The development of vectors such as P1, P1-derived artificial chromosome (PAC) or bacterial artificial chromosome (BAC) $(2,6,8)$ has permitted the cloning of large DNA fragments. These vectors have become common in largescale sequencing and mapping projects. Therefore, a reliable primer walking protocol for P1 plasmids is desirable.

It has been demonstrated previously that sequencing of P1 plasmid DNA is generally feasible $(4,11)$. However, the protocols included several laborious steps such as a host strain change from NS3145 to DH10B or tedious purification procedures and were limited to the use of primers located in the vector arms. Another development for sequencing P1 plasmid DNA uses a polymerase chain reaction (PCR)-based technique termed "thermal asymmetric interlaced PCR" (5); however, this method also relies on numerous experimental steps. We present an optimized sequencing protocol for direct primer walking on P1 plasmid DNA based on cycle sequencing (7).

The effect of the following parameters on the success rate of $\mathrm{P} 1$ sequencing was evaluated: host cell type, purification procedure, template amount, primer design, primer amount and cycle sequencing conditions. Sequencing reactions were carried out with either fluorescein isothiocyanate (FITC)- or Cy5 $5^{\mathrm{TM}}$-labeled primers and analyzed on the corresponding sequencing apparatus (ALF DNA Sequencer ${ }^{\mathrm{TM}}$ and ALFexpress $^{\mathrm{TM}}$; Pharmacia Biotech, Piscataway, NJ, USA). The read length assigned to sequencing results was determined by the number of nucleotides called after automatic processing by the ALF software.

P1 plasmid DNA was isolated from its $E$. coli host strain NS3145 (library strain) and transformed into the new host strain DH10B by electroporation (3). When performing parallel P1 plasmid DNA preparations under identical conditions ( $2 \times$ YT medium, $0.5-\mathrm{L}$ culture volume, $50 \mu \mathrm{g} / \mathrm{mL}$ kanamycin, single-colony inoculate, two QIAGEN ${ }^{\circledR}$ 100 columns [Qiagen, Hilden, Germany]), the E. coli host strain NS3145 consistently yielded between 5 and 8 times more P1 plasmid DNA than the DH10B host strain. On average, a 0.5-L culture (NS3145 strain) yielded $80 \mu \mathrm{g}$ $( \pm 10 \%)$ plasmid DNA.

P1 plasmid DNA purification was performed with a conventional alkaline lysis/phenol:chloroform protocol (1) (Nucleobond ${ }^{\circledR}$; Macheray and Nagel, Düren, Germany) or an alkaline lysis protocol followed by column purification (Qiagen). The Nucleobond and the Qiagen protocols provided by the suppliers were both modified as follows. Lysis time was shortened from 5 to 1 min, and volumes of the resuspension, lysis and neutralization buffers were

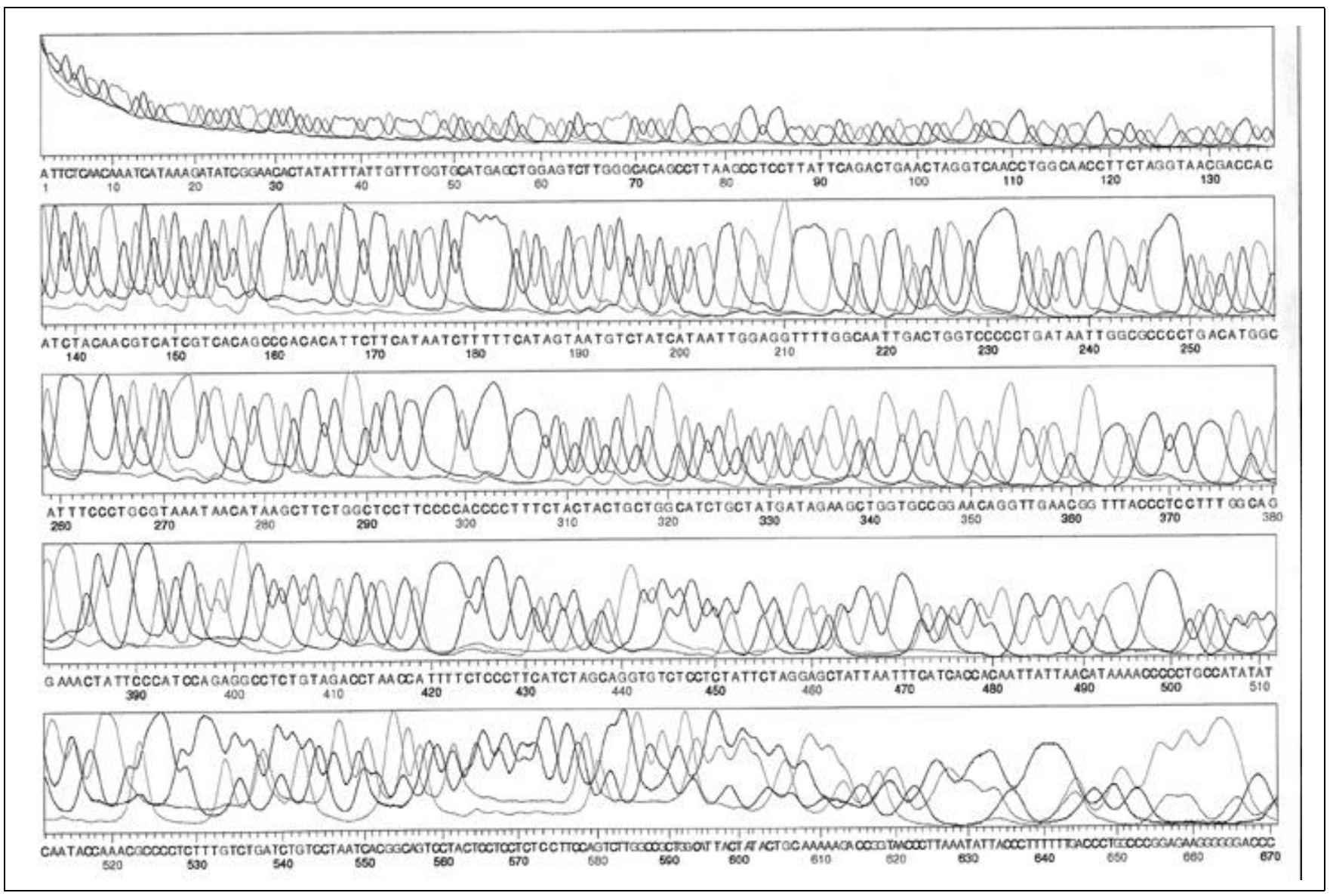

Figure 1. Direct P1 plasmid sequencing using 6 pmol of an FITC-labeled primer (20-mer) and $8 \mu \mathrm{g}$ of column-purified P1 plasmid DNA. 
Table 1. Overview of Walks Performed on P1 Plasmid DNA

\begin{tabular}{|c|c|c|c|c|c|}
\hline Clone Number & $\begin{array}{c}\text { Number of } \\
\text { Primers Used }\end{array}$ & $\begin{array}{c}\text { Bases Read in } \\
\text { Each Sequencing } \\
\text { Reaction }\end{array}$ & $\begin{array}{l}\text { Number of Failed } \\
\text { Sequencing } \\
\text { Reactions }\end{array}$ & $\begin{array}{l}\text { Average Length } \\
\text { Read }\end{array}$ & $\begin{array}{l}\text { Total Bases } \\
\text { Sequenced }\end{array}$ \\
\hline $3 A$ & 11 & $\begin{array}{l}253,345,423,253 \\
487,253,418,578 \\
405,487,337\end{array}$ & 0 & 385 bases & 4239 bases \\
\hline $6 \mathrm{~A}$ & 10 & $\begin{array}{l}323,271,100,251 \\
0,334,266,549 \\
505,508\end{array}$ & 1 & 311 bases & 3107 bases \\
\hline $12 B$ & 23 & $\begin{array}{l}534,279,360,329, \\
384,239,194,273, \\
149,441,619,408, \\
476,413,348,633, \\
168,462,448,649, \\
513,661,617\end{array}$ & 0 & 417 bases & 9597 bases \\
\hline Total & 44 & & 1 & 385 bases & 16943 bases \\
\hline
\end{tabular}

doubled. Elution was done with preheated buffer $\left(55^{\circ} \mathrm{C}\right)$ and a volume increased by one fourth. In both cases, the precipitated P1 plasmid DNA was rinsed twice with $70 \%$ ethanol. Care was taken not to overdry the pellet after the final wash. Multiple sequencing reactions were performed on plasmid DNA grown in either NS3145 or DH10B (EleCtRoMAX ${ }^{\mathrm{TM}}$; Life Technologies, Berlin, Germany) and isolated by both methods.

DNA purified from the host strain NS3145 yielded better sequencing results than identical amounts from the host strain DH10B. Although plasmid DNA isolated by conventional alkaline lysis/phenol:chloroform purification yielded usable sequence, column purification reduced the background in the sequencing reactions and produced longer readouts with fewer ambiguities.

Best results were obtained when 5-10 $\mu \mathrm{g}$ of plasmid DNA were used in the reaction. Thus, substantially larger amounts of DNA are necessary for successful cycle sequencing of P1 clones than of smaller multicopy plasmids.

Walking primers were selected and designed with the aid of the European Molecular Biology Laboratory (EMBL) integrated software package GeneSkipper (9). In general, primers were designed by choosing a region with the highest possible melting temperature (calculated melting temperatures were above $45^{\circ} \mathrm{C}$ ). This approach makes it possible to use a high annealing temperature during cycle sequencing and thus to reduce nonspecific priming events. Primers either 20 or 27 nucleotides in length were tested. There was no noteworthy difference in their performance. Walking primers were placed an average of 40 bases away from the end of the sequence determined by the previously used primer.

The optimal amount of primer was found to be 6 pmol with a range of 4-10 pmol per reaction giving good results. Too high an amount of primer led to nonspecific priming, which rendered sequence interpretation difficult. Best results were achieved with a two-step cycling protocol as follows: (i) initial denaturation at $95^{\circ} \mathrm{C}$ for $3 \mathrm{~min}$ and (ii) 40 cycles at $60^{\circ} \mathrm{C}$ for $30 \mathrm{~s}$ and $95^{\circ} \mathrm{C}$ for 30 s. In general, the commercially available Thermo Sequenase ${ }^{\mathrm{TM}}$ Kit (Amersham International plc, Cambridge, England, UK) (10) was used. However, other enzymes performed equally well (data not shown).

Applying the above protocol, 44 primer walks on various $\mathrm{P} 1$ clones have been performed, and almost $17 \mathrm{~kb}$ of sequence have been determined. The average reading length per sequencing reaction was 385 bases using $30-\mathrm{cm}$ glass plates. The estimated sizes of the clones (about $95 \mathrm{~kb}$ ) were well within the range of average $\mathrm{P} 1$ clones. The above protocol has been applied to BAC clones with equal success. Table 1 gives an overview of all walks performed on P1 plasmid DNA, and Figure 1 shows a typical sequencing reaction.

In summary, a bacterial host strain change is superfluous when $\mathrm{P} 1$ plasmid DNA for sequencing is prepared, because DNA isolated from the NS3145 strain performs well in cycle sequencing. The best results were obtained using 5-10 $\mu \mathrm{g}$ of P1 plasmid DNA and 6 pmol of fluorescently labeled primer in combination with a two-step cycle sequencing protocol with a high annealing temperature $\left(60^{\circ} \mathrm{C}\right)$. Column-purified DNA performed better than DNA isolated by alkaline lysis only.

Note Added in Proof: We recently found that a cycling protocol consisting of an initial denaturation at $95^{\circ} \mathrm{C}$ for 3 min and 40 cycles at $60^{\circ} \mathrm{C}$ for $30 \mathrm{~s}$, $68^{\circ} \mathrm{C}$ for $30 \mathrm{~s}$ and $95^{\circ} \mathrm{C}$ for $30 \mathrm{~s}$ further improves the average length read.

\section{REFERENCES}

1.Birnboim, H.C. and J. Doly. 1979. A rapid alkaline extraction procedure for screening recombinant plasmid DNA. Nucleic Acids Res. 7:1513-1523 
2.Ioannou, P.A., C.T. Amemiya, J. Garnes, P.M. Kroisel, H. Shizuya, C. Chen, M.A. Batzer and P. de Jong. 1994. A new bacteriophage P1-derived vector for the propagation of large human DNA fragments. Nat. Genet. 6:84-89.

3.Kilger, C. and H. Zischler. 1997. Electrotransformation of bacterial cells with P1 plasmid DNA. Trends Genet. 13:41.

4.Kimmerly, W.J., A.L. Kyle, V.M. Lustre, C.H. Martin and M.J. Palazzolo. 1994. Direct sequencing of terminal regions of genomic P1 clones. Genet. Anal. Tech. Appl. 11:117128.

5.Liu,Y.G. and R.F. Whittier. 1995. Thermal asymmetric interlaced PCR: automatable amplification and sequencing of insert end fragments from P1 and YAC clones for chromosome walking. Genomics 25:674-681.

6.Monaco, A.P. and Z. Larin. 1994. YACs, BACs and MACs: artificial chromosomes as research tools. Trends Biotechnol. 12:280286.

7.Murray, V. 1989. Improved double-stranded DNA sequencing using the linear polymerase chain reaction. Nucleic Acids Res. 17:8889.

8.Pierce, J.C., B. Sauerand and N. Sternberg. 1992. A positive selection vector for cloning high molecular weight DNA by the bacteriophage P1 system: improved cloning efficacy. Proc. Natl. Acad. Sci. USA 89:2056-2060.

9.Schwager, C., S. Wiemann and W. Ansorge. 1995. GeneSkipper-an integrated software environment for DNA sequence assembly and analysis. Genome Digest 2:8-9.

10.Tabor, S. and C.C. Richardson. 1995. A single residue in DNA polymerases of the Escherichia coli DNA polymerase I family is critical for distinguishing between deoxy- and dideoxyribonucleotides. Proc. Natl. Acad. Sci. USA 92:6339-6343.

11.Wang, Q. and M.T. Keating. 1994. Isolation of P1 insert ends by direct sequencing. BioTechniques 17:282-284.

The excellent synthesis of fluorescently labeled primers by Heiko Drzonek and Walter Schartau as well as the fine technical support by Karin Bauer are gratefully acknowledged. Financial support came from the DFG. Address correspondence to Christian Kilger, Institute of Zoology, University of Munich, P.O. Box 202126, D-80021 Munich, Germany. Internet: kilger@zi. biologie.uni-muenchen.de

Received 7 August 1996; accepted 24 January 1997.

\section{Benes, C. Kilger ${ }^{1}$, H. Voss, S. Pääbo ${ }^{1}$ and W. Ansorge European Molecular Biology Laboratory \\ Heidelberg \\ ${ }^{1}$ University of Munich \\ Munich, Germany}

\section{Fabrication of Ion-Selec- tive Microelectrodes by a Centrifugation/Suction Method}

\author{
BioTechniques 23:100-102 (July 1997)
}

The preparation of ion-selective microelectrodes can be both time-consuming and frustrating. Since most techniques involve filling the tip with resin before back-filling the rest of the electrode with electrolyte, the step most commonly found annoying is the elimination of air bubbles between the electrolyte and the resin. Since the tip is not visible, trying to draw liquid ion exchanger (LIX) into a plugged electrode tip is also frustrating. In fabricating calcium ion-sensitive microelectrodes for use as extracellular vibrating probes, Kühtreiber and Jaffe (2) avoided these problems by sequential suction-frontfilling, first with electrolyte and then with resin. Although these steps precluded the problem of air bubbles between the two filling materials, the electrodes described had open tips of 1-10 $\mu \mathrm{m}$. Intracellular ion-selective electrodes require smaller tip sizes, and front-filling the electrolyte becomes inconvenient (1) or impossible. Back-filling the tip through the capillary action

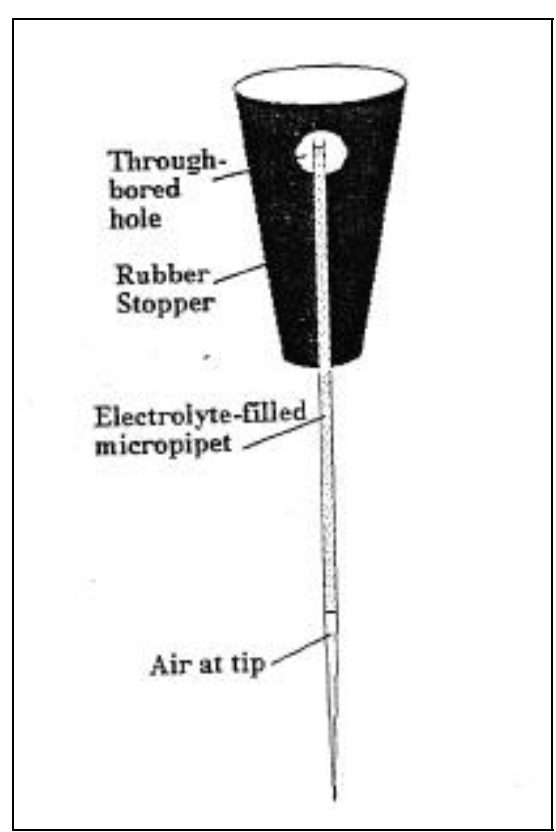

Figure 1. Holder for electrolyte filling of micropipet tips by centrifugation. of a filling fiber $(3,5)$ is undoubtedly the most common practice today for preparing standard potassium chloride electrodes, but due to the hydrophobicity of the coating, silane-coated micropipets cannot be filled in this manner. Yet, if the problem of fully filling the electrode tip with electrolyte can be overcome, the advantage of subsequent bubble-free front-filling with LIX can be achieved. I describe a simple technique by which this may be accomplished and that nearly always results in a useful ion-selective electrode.

First, electrodes are batch-silanecoated. Depending on the method of silane coating employed, capillary glass tubing used may be either with or without filling fibers. The technique I use is based on procedures described by Spray and Zavilowitz (4) for doublebarreled electrodes, but works well with single-barreled electrodes with a filling fiber. One part trimethylchlorosilane (silane) (Sigma Chemical, St. Louis, MO, USA) is mixed with 10 parts carbon tetrachloride. A small amount of silane is introduced into the back of the electrode and allowed to move into the tip. Because of the filling fiber and the low surface tension of the solution, the silane travels easily to the tip. Excess solution is then withdrawn, and the electrodes are placed horizontally in a carrier made from an aluminum block and baked in an oven at

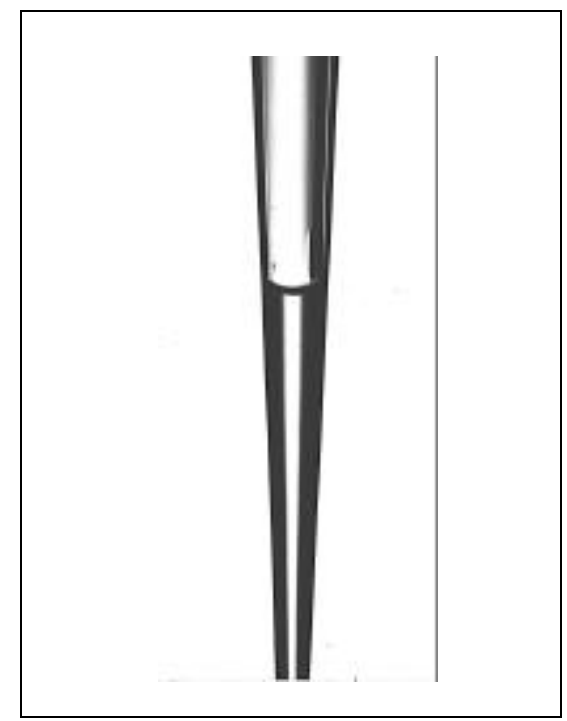

Figure 2. A smooth interface free from air bubbles results when LIX is drawn into a microelectrode previously filled with electrolyte. 